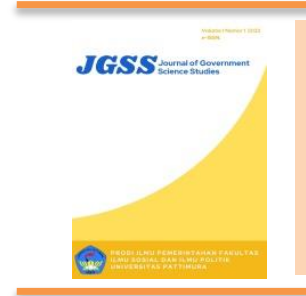

Journal of Government Science Studies

Available online at https://ojs3.unpatti.ac.id/

Vol. 1 No. 1, April 2022, pages: 28-37

e-ISSN: 2827-847X, p-ISSN: 2827-8461

https://doi.org/10.53730

\title{
Partisipasi Perempuan dalam Perencanaan Pembangunan di Ohoi Elaar Lamagorang Kecamatan Kei Kecil Timur Selatan Maluku Tenggara
}

\author{
James Labetubun ${ }^{a}$ \\ Email Corespondensi: lebetubun1995@gmail.com
}

Manuscript submitted: 27-01-2022, Manuscript revised: 31-01-2022, Accepted for publication: 01-02-2022

Kata Kunci:
Partisipasi
Perempuan 1;
Pemberdayaan
Masyarakat 2;
Rencana
Pembangunan 3;
Kualitas Perempuan
4.

\begin{abstract}
Abstrak: Tingkat partisipasi perempuan yang masih rendah dalam perencanaan pembangunan masih sangat minim sehingga program yang berpihak kepada kaum wanita tidak pernah ada dalam program pemberdayaan masyarakat. Faktor menjadi hambatan yaitu perempuan masih sibuk dengan urusan rumah tangga dan keluarga serta pengetahuan yang masih sangat rendah. Penelitian yang digunakan adalah deskriptif kualitatif dengan wawancara secara mendalam dengan masyarakat bersama kepala adat. Hasil penelitian yang diperoleh adalah (1). perempuan minim terlibat dalam musyawarah rencana pembangunan di Ohoi Elaar Lamagorang yakni budaya. (2). Kuantitas perempuan yang dilibatkan dalam musyawarah rencana pembangunan Ohoi Elaar Lamagorang masih sedikit. (3) kuantitas kontribusi pemikiran perempuan yang dilibatkan dalam musyawarah rencana pembangunan di Ohoi Elaar Lamagorang sangat minim.
\end{abstract}

\footnotetext{
${ }^{a}$ Universitas Pattimura, Indonesia
} 


\section{Pendahuluan}

Pemberdayaan sesungguhnya harus memberi celah pada kaum wanita untuk tetap bisa berkarya dan berkreatifitas. Kaum wanita sekarang sudah tidak bisa dipandang seperti wanita pada jaman dahulu karena pada perkembangannya, ternyata wanita juga bisa memberikan sumbangsih berupa ide, tenaga, dan waktu dalam menciptakan suatu inovasi yang dapat diterapkan di desa untuk pembangunan desa. Menciptakan kolaborasi maksimal dalam membangun desa yang lebih baik, maka kolaborasi antara berbagai elemen harus bisa diajak demi menyatukan satu visi dan misi tanpa mendikotomikan gender sebagai bias jurang yang memisahkan. (Goetze, Denis, 2016).

Menurut Ihalau (2008), mengatakan teori adalah bangunan fisik yang merekonstruksi hubungan berbagai konsep yang memiliki pengertian tersendiri sesuai dengan proposisi yang menjalaninya. Untuk memberikan pemaham tentang permasalahan yang diteliti, maka teori yang akan digunakan dalam penelitian ini yakni ; (a) partisipasi, (b) hambatan partisipasi perempuan, (c) pembangunan, (d) pembangunan inprastruktur, dan (e) desa (Ihalau, 2008). Partisipasi bisa bersifat transitif atau intransistif, bisa pula bermoral atau tak bermoral (Khairul Muluk 2010).

Menurut Antoft dan Novack (2010), adalah esuatu yang bisa dilakukan oleh komunitas untuk memperjuangkan kepentingan dan kebutuhannya. Bentuknya bisa berlangsung secara simultan untuk memberikan kesempatan kepada penduduk untuk menikmati akses partisipasi yang lebih besar karena tidak semua penduduk pada waktu yang bersamaan, di tempat yang sama, dengan kepentingan yang sama dapat berpartisipasi secara langsung dan bersama-sama (Antoft dan Novack 2010). Partipasi terbagi menjadi dua yaitu, Pertama, memiliki sejumlah atribut, benda atau kualitas dari seseorang. Kedua, mengambil bagian dalam suatu kegiatan atau membagi sesuatu dalam kebersamaan (Said, dkk, 2004). Pelaksanaan program dilakukan melalui dua tahapan yaitu persiapan dan pelaksanaan (Wance, Muhtar, Kaliky, 2020).

Harisun (2011) mendefenisikan pembangunan adalah segala upaya yang dilakukan secara terencana dalam melakukan perubahan dengan tujuan utama memperbaiki dan meningkatkan taraf hidup masyarakat, meningkatkan kesejahteraan dan meningkatkan kualitas manusia. Sedangkan Bukhori (1993) mendefenisikan pembangunan sebagagai suatu istilah teknis, yang berarti membangkitkan masyarakat di negara-negara berkembang dari kemsikinan, tingkat melek huruf (literacy rate) yang rendah, pengangguran, dan ketidakadilan sosial. Senada dengan itu, Fandi (2006) mendefenisikan pembangunan sebagai perubahan menuju pola-pola masyarakat yang lebih baik. Sementara itu, Robert (1998) mendefenisikan pembangunan sebagai jenis perubahan sosial. Modalitas sangat dibutuhkan kandidat dalam melakukan akomodasi kekuatan (Wance, Djae, 2019).

Selain itu, Santoso ( 1998) bahwa partisipasi masyarakat itu penting dalam pembagunan karena :

1. Partisipasi masyarakat merupakan suatu alat guna memperoleh imformasi mengenai kondisi, kebutuhan, dan sikap masyarakat setempat yang tanpa kehadirannya program pembangunan akan gagal.

2. Masyarakat akan lebih mempercayai program pembangunan jika merasa melibatkan dalam proses persiapan dan perencanaan, karena mereka akan mengetahui seluk beluk pembangunan teresbut.

3. Merupakan hak demokrasi bila masyarakat di libatkan dalam pembangunan masyarakat sendiri. 
Secara teori Hasibuan (2007) menjelaskan tentang kendala dalam mewujudkan partisipasi perempuan hususnya dalam ruang publik. Perempuan hanya baik dan sukses apabila dia menjalankan kodratnya sebahagai mahluk reproduksi semata, dan bukan bekerja di domain kepemerintahan, the nature theory (Budiman, 1981). Pelaksanaan konsep kemitraan kebijakan organisasi menjadi faktor keberhasilan implementasi program organisasi pemerintah ( Tuanaya, Wance, 2021).

Fenomena ini secara rill ditemui di Ohoi Elaar Lamagorang Kecamatan Kei Kecil Timur Selatan Kabupaten Maluku Tenggara. Partisipasi perempuan dalam perencanaan pembangunan di ohoi ini masih minim, jika dibandingkan dengan partisipasi kaum pria dalam perencanaan pembangunan di ohoi ini. Setelah diamati (observasi), ternyata terdapat beberapa faktor penghambat partsipasi perempaun dalam partisipasi pembangunan di Ohoi Elaar Lamagorang, antara lain :

1. Faktor budaya, dimana kaum perempuan masih dianggap sebagai insan yang hanya mengurusi kebutuhan rumah tangga, tanpa perlu terlibat dalam persoalan perencanaan pembangunan di ohoi.

2. Partisipasi dalam perencanaan pembangunan ohoi dianggap merupakan kompetensi dari kaum pria. Sehingga keterlibatan kaum pria dalam pembangunan ohoi merupakan sesuatu yang realistis.

3. Masih adanya sikap apatis dari kaum perempuan untuk berpartisipasi dalam perencanaan pembangunan di ohoi.

4. Masih rendahnya kualitas sumber daya manusia (SDM) kaum perempuan untuk berpartisipasi dalam setiap perencanaan pembangunan di ohoi.

\section{Metode Penelitian}

Penelitian deskriptif kualitatif tidak dimaksudkan untuk membuat generalisasi dari hasil penelitiannya, dimana penelitian yang dilakukan untuk mengetahui nilai variabel mandiri, baik satu variabel atau lebih (independen) tanpa membuat perbandingan, atau menghubungkan dengan variabel yang lain. Oleh karena itu, pada penelitian deskriptif kualitatif tidak dikenal adanya populasi dan sampel. Sebab penelitian deskriptif kualitatif berangkat dari kasus tertentu yang ada pada situasi sosial tertentu dan hasil kajiannya tidak akan diberlakukan ke populasi, tetapi ditransferkan ke tempat lain pada situasi sosial yang memiliki kesamaan dengan situasi sosial pada kasus yang dipelajari. Sampel di dalam penelitian deskriptif kualitatif tidak dinamakan responden tetapi dinamakan narasumber, partisipan, dan informan. (Sugiyono, 2003).

Subjek penelitian yang telah tercermin dalam fokus penelitian ditentukan secara sengaja. Subjek penelitian ini menjadi informan yang akan memberikan berbagai informasi yang diperlukan selama proses penelitian, informan penelitian ini meliputi beberapa macam seperti : (1) informan kunci, yaitu mereka yang mengetahui dan memiliki berbagai informasi pokok yang diperlukan dalam penelitian; (2) informan utama, yaitu mereka yang terlibat langsung dalam interaksi sosial yang diteliti ; (3) informan tambahan, yaitu mereka yang dapat memberikan informasi walaupun tidak langsung terlibat dalam interaksi sosial yang diteliti (Suyanto, 2008). Menyangkut daftar informan utama, kunci dan informan tambahan dapat dilihat pada tabel 1 dibawah ini :

Lebetubun, J. (2022). Partisipasi Perempuan dalam Perencanaan Pembangunan di Ohoi Elaar Lamagorang Kecamatan Kei Kecil Timur Selatan Maluku Tenggara. Journal of Government Science Studies, 1(1). 
Tabel 1

Informan Kunci, Informan Utama, dan Informan Tambahan

\begin{tabular}{|c|c|c|}
\hline Nama Target & Status & Alasan Pemilihan \\
\hline Raja Ohoi Elaar Lamagorang & $\begin{array}{l}\text { Informan } \\
\text { Kunci }\end{array}$ & $\begin{array}{lr}\text { Untuk } & \text { mengetahui } \\
\text { tanggapan } & \text { tentang } \\
\text { partisipasi } & \text { perempuan } \\
\text { dalam } & \text { perencanaan } \\
\text { pembangunan di Ohoi } \\
\text { Elaar Lamagorang }\end{array}$ \\
\hline $\begin{array}{l}\text { Tokoh Perempuan di Ohoi } \\
\text { Elaar Lamagorang }\end{array}$ & $\begin{array}{l}\text { Informan } \\
\text { Utama }\end{array}$ & $\begin{array}{lr}\text { Untuk mengetahui } \\
\text { tanggapan } & \text { tentang } \\
\text { partisipasi } & \text { perempuan } \\
\text { dalam } & \text { perencanaan } \\
\text { pembangunan di Ohoi } \\
\text { Elaar Lamagorang }\end{array}$ \\
\hline $\begin{array}{l}\text { Tokoh Masyarakat di Ohoi } \\
\text { Elaar Lamagorang }\end{array}$ & $\begin{array}{l}\text { Informan } \\
\text { Tambahan }\end{array}$ & $\begin{array}{lr}\text { Untuk mengetahui } \\
\text { tanggapan } & \text { tentang } \\
\text { partisipasi } & \text { perempuan } \\
\text { dalam } & \text { perencanaan } \\
\text { pembangunan di Ohoi } \\
\text { Elaar Lamagorang }\end{array}$ \\
\hline $\begin{array}{l}\text { Tokoh Adat di Ohoi Elaar } \\
\text { Lamagorang }\end{array}$ & $\begin{array}{l}\text { Informan } \\
\text { Tambahan }\end{array}$ & $\begin{array}{lr}\text { Untuk } & \text { mengetahui } \\
\text { tanggapan } & \text { tentang } \\
\text { partisipasi } & \text { perempuan } \\
\text { dalam } & \text { perencanaan } \\
\text { pembangunan di Ohoi } & \text { diar Lamagorang }\end{array}$ \\
\hline
\end{tabular}

Sumber data, hasil analisis penelitian

\section{Hasil dan Diskusi}

Perempuan dan desa merupakan dua entitas yang tidak bisa dipisahkan. Desa sebagai unit adminstrasi kecil dalam pemerintahan sudah semestinya tidak melihat perempuan sebagai entitas yang "selalu dikalahkan". Maka era baru, bersamaan dengan Undang-Undang Nomor 6 Tahun 2014 Tentang Desa, menjadi peluang besar bagi perempuan untuk "merebut" ruang-ruang yang selama ini didominasi laki-laki. Perempuan-perempuan desa sudah saatnya berkuasa atas diri dan pikirannya, sehingga memiliki ruang yang setara dalam lembaga-lembaga desa yang ada. Tentu saja ini pekerjaan besar dan tidak mudah.

Khususnya dalam proses perencanaan pembangunan, perempuan kerap tidak dilibatkan. Perempuan seolah hanya menjadi pelengkap dalam forum-forum warga. Tantangan kultural harus didobrak untuk membuka ruang dan akses perempuan terhadap proses pembangunan di desa. Oleh karena itu, dalam proses perencanaan pembangunan tidak boleh meniadakan satu pun entitas di desa. Sebab, setiap entitas di desa berhak untuk terlibat dalam proses perencanaan pembangunan tanpa terkecuali. Begitu pula perempuan harus dilibatkan dalam perencanaan pembangunan di desa. 


\section{Kesadaran Perempuan Untuk Berpartisipasi Dalam Musyawarah Rencana Pembangunan Ohoi}

Partisipasi perempuan dalam musyawarah perencanaan pembangunan (musrenbang) desa masih sangat rendah. Rendahnya partisipasi tersebut disebabkan oleh beberapa hal seperti rendahnya akses perempuan terhadap informasi, perempuan dipersepsikan memiliki kewajiban dalam pekerjaan domestik sehingga akan muncul isu beban ganda, pendominasian partisipasi dari kaum elit (pemerintah desa), ketimpangan hak perempuan dalam akses pendidikan, dan masih kuatnya budaya patriarki.

Partisipasi Perempuan dalam Musrenbang merupakan isu yang sudah diwacanakan oleh teman-teman di gerakan perempuan sejak beberapa tahun lalu. Tujuannya tdak lain dan tidak bukan yakni memastikan partisipasi dan suara perempuan masuk dalam rencana pembangunan baik dari tingkat lokal hingga tingkat nasional. Oleh karena, kita menyadari bahwa partisipasi dan suara kelompok perempuan masih sangat terbatas karena berbagai hal. Persoalan budaya, politik, kebijakan dan kesempatan adalah beberapa hal yang menjadikan mengapa partisipasi perempuan sangat rendah dalam perencanaan pembangunan.

Di Ohoi Elaar Lamagorang Kecamatan Kei Kecil Timur Selatan Kabupaten Maluku Tenggara menghadapi fenomena yang sama, dimana kesadaran perempuan untuk berpartisipasi dalam musyawarah rencana pembangunan ohoi masih minim. Menyangkut dengan hal ini berikut wawancara peneliti dengan Raja Ohoi Elaar Lamagorang, pada 20 Oktober 2016 di Ohoi Elaar Lamagorang, bahwa :

"Pada kenyataan di Ohoi Elaar Lamagorang kesadaran perempuan untuk berpartisipasi dalam musyawarah rencana pembangunan ohoi masih minim. Sebab rata-rata para perempuan masih sibuk dengan aktifitasnya masing-masing, baik itu sebagai ibu rumah tanggah dan sebagai pekerja di instansi pemerintah dan swasta. Sehingga tidak bisa menyempatkan waktunya untuk mengikuti musyawarah rencana pembangunan ohoi. Padahal Pemerintah Ohoi Elaar Lamagorang sudah mensosialisasikan kepada para perempuan untuk mengikuti musyawarah rencana pembangunan ohoi, karena dalam musyawaran ini terdapat program-program yang terkait dengan kebutuhan perempuan, namun mereka tidak terlalu antusias terhadapnya. Akibatnya peserta musyawarah rencana pembangunan ohoi didominasi oleh kaum pria."

Dari wawancara tersebut dapat diketahui bahwa, di Ohoi Elaar Lamagorang kesadaran perempuan untuk berpartisipasi dalam musyawarah rencana pembangunan ohoi masih minim. Sebab rata-rata para perempuan masih sibuk dengan aktifitasnya masing-masing, baik itu sebagai ibu rumah tanggah dan sebagai pekerja di instansi pemerintah dan swasta. Sehingga tidak bisa menyempatkan waktunya untuk mengikuti musyawarah rencana pembangunan ohoi. Padahal Pemerintah Ohoi Elaar Lamagorang sudah mensosialisasikan kepada para perempuan untuk mengikuti musyawarah rencana pembangunan ohoi, karena dalam musyawaran ini terdapat program-program yang terkait dengan kebutuhan perempuan, namun mereka tidak terlalu antusias terhadapnya. Akibatnya peserta musyawarah rencana pembangunan ohoi didominasi oleh kaum pria.

Terlepas dari itu, kesadaran perempuan untuk berpartisipasi dalam musyawarah rencana pembangunan ohoi tentu merupakan aspek vital. Sebab akan mampu menjawab kebutuhan perempuan terkait dengan pemenuhan program-program yang berpihak pada perempuan, seperti : pendirian WC khusus bagi perempuan, tempat mandi dan mencuci bagi perempuan, kesehatan bagi perempuan, dan program pemenuhan pangan kepada perempuan. Menyangkut dengan hal ini berikut wawancara peneliti tokoh perempuan yang masing-masing berinisial (DM, SM, SL, MW, LM dan ML) di Ohoi Elaar Lamagorang pada 22 Oktober 2016 di Ohoi Elaar Lamagorang, dimana kesemuanya memiliki orientasi jawaban yang sama sehingga tanggapan mereka langsung

Lebetubun, J. (2022). Partisipasi Perempuan dalam Perencanaan Pembangunan di Ohoi Elaar Lamagorang Kecamatan Kei Kecil Timur Selatan Maluku Tenggara. Journal of Government Science Studies, 1(1). 
disatukan sebagai hasil wawancara yakni :

"Kesadaran perempuan untuk berpartisipasi dalam musyawarah rencana pembangunan Ohoi Elaar Lamagorang masih sedikit. Hal ini tidak terlepas dari persepsi para perempuan di Ohoi Elaar Lamagorang jika keterlibatan mereka dalam musyawarah rencana pembangunan Ohoi Elaar Lamagorang merupakan kewenangan dari para pria untuk berpartisipasi aktif. Persepsi ini terbangun di pemikiran para perempuan, tidak terlepas juga dari budaya setempat yang menanggap permasalahan musyawarah rencana pembangunan Ohoi Elaar Lamagorang hanya memerlukan keterlibatan para pria. Persepsi inilah yang menjadi salah satu aspek penghambat untuk keterlibatan para perempuan dalam musyawarah rencana pembangunan Ohoi Elaar Lamagorang."

Dari wawancara tersebut dapat diketahui bahwa, kesadaran perempuan untuk berpartisipasi dalam musyawarah rencana pembangunan Ohoi Elaar Lamagorang masih kurang/sedikit. Hal ini tidak terlepas dari persepsi para perempuan di Ohoi Elaar Lamagorang jika keterlibatan mereka dalam musyawarah rencana pembangunan Ohoi Elaar Lamagorang merupakan kewenangan dari para pria untuk berpartisipasi aktif. Persepsi ini terbangun di pemikiran para perempuan, tidak terlepas juga dari budaya setempat yang menanggap permasalahan musyawarah rencana pembangunan Ohoi Elaar Lamagorang hanya memerlukan keterlibatan para pria. Persepsi inilah yang menjadi salah satu aspek penghambat untuk keterlibatan para perempuan dalam musyawarah rencana pembangunan Ohoi Elaar Lamagorang.

\section{Kuantitas Perempuan Yang Dilibatkan Dalam Musyawarah Rencana Pembangunan Ohoi}

Kuantitas perempuan yang dilibatkan dalam musyawarah rencana pembangunan ohoi (desa) merupakan suatu keharusan. Pasalnya semakin tinggi kuantitas perempuan yang dilibatkan dalam musyawarah rencana pembangunan ohoi (desa), tentunya akan berkolerasi dengan aspek kesamarataan, dan keadilan perlakuan terhadap perempuan. Sehingga pada akhirnya berbagai kebutuhan perempuan akan terimplementasikan didalam musyawarah rencana pembangunan ohoi (desa).

Atas dasar itu, maka untuk mengukur derajat demokratisnya suatu ohoi (desa) pada satu kabupaten/kota tertentu, akan sangat tergantung pada seberapa besar kuantitas perempuan yang dilibatkan dalam musyawarah rencana pembangunan ohoi (desa). Jika besar kuantitas perempuan yang dilibatkan dalam musyawarah rencana pembangunan ohoi (desa), maka tentunya dikategorikan demokratis. Sebaliknya semakin kecil kuantitas perempuan yang dilibatkan dalam musyawarah rencana pembangunan ohoi (desa), maka dikategorikan tidak demokratis.

Dalam perkembangannya di tanah air, kuantitas perempuan yang dilibatkan dalam musyawarah rencana pembangunan ohoi (desa), termasuk juga pada kabupaten/kota di Provinsi Maluku menjadi perhatian serius. Tidak terkecuali kuantitas perempuan yang dilibatkan dalam musyawarah rencana pembangunan di Ohoi Elaar Lamagorang Kecamatan Kei Kecil Timur Selatan Kabupaten Maluku Tenggara. Menyangkut dengan hal itu, berikut wawancara peneliti dengan Raja Ohoi Elaar Lamagorang, pada 20 Oktober 2016 di Ohoi Elaar Lamagorang, bahwa :

"Seperti yang dikatakan sebelumnya bahwa kuantitas perempuan yang dilibatkan dalam musyawarah rencana pembangunan Ohoi Elaar Lamagorang masih sedikit. Sebab rata-rata para perempuan masih sibuk dengan aktifitasnya masing-masing, baik itu sebagai ibu rumah tanggah dan sebagai pekerja di instansi pemerintah dan swasta. Konsekuensinya mereka tidak bisa menyempatkan waktunya untuk mengikuti musyawarah rencana pembangunan ohoi. Padahal sebelumnya Pemerintah Ohoi Elaar Lamagorang sudah mensosialisasikan kepada para perempuan untuk mengikuti musyawarah rencana pembangunan ohoi, karena dalam musyawaran ini terdapat program-program yang terkait dengan kebutuhan 
perempuan, namun mereka tidak terlalu antusias terhadapnya. Kondisi ini berdampak juga pada dominasi kaum pria sebagai peserta musyawarah rencana pembangunan ohoi didominasi oleh kaum pria."

Dari wawancara tersebut dapat diketahui bahwa, kuantitas perempuan yang dilibatkan dalam musyawarah rencana pembangunan Ohoi Elaar Lamagorang masih sedikit. Sebab rata-rata para perempuan masih sibuk dengan aktifitasnya masing-masing, baik itu sebagai ibu rumah tanggah dan sebagai pekerja di instansi pemerintah dan swasta. Konsekuensinya mereka tidak bisa menyempatkan waktunya untuk mengikuti musyawarah rencana pembangunan ohoi. Padahal sebelumnya Pemerintah Ohoi Elaar Lamagorang sudah mensosialisasikan kepada para perempuan untuk mengikuti musyawarah rencana pembangunan ohoi, karena dalam musyawaran ini terdapat program-program yang terkait dengan kebutuhan perempuan, namun mereka tidak terlalu antusias terhadapnya. Kondisi ini berdampak juga pada dominasi kaum pria sebagai peserta musyawarah rencana pembangunan ohoi didominasi oleh kaum pria.

Terlepas dari itu, kuantitas perempuan yang dilibatkan dalam musyawarah rencana pembangunan Ohoi Elaar Lamagorang perlu ditingkatkan pada masa yang akan datang. Pasalnya semakin tinggi kuantitas perempuan yang dilibatkan dalam musyawarah rencana pembangunan Ohoi Elaar Lamagorang, maka tentunya akan berkolerasi dengan aspek kesamarataan, dan keadilan perlakuan terhadap perempuan di Ohoi Elaar Lamagorang. Sehingga pada akhirnya berbagai kebutuhan perempuan akan terimplementasikan didalam musyawarah rencana pembangunan di Ohoi Elaar Lamagorang. Menyangkut dengan hal itu, berikut peneliti akan menyampaikan hasil wawancara peneliti dengan Tokoh Masyarakat di Ohoi Elaar Lamagorang yang terdiri dari Bapak Okto Renoat, Bapak Pieter Madubun dan Bapak Yoseph Faudubun pada 22 Oktober 2016 di Ohoi Elaar Lamagorang. Adapun hasil wawancara dari tokoh masyarakat ini kemudian disatukan jawaban mereka karena memeliki kesamaan jawabannya, sebagaimana terlihat berikut ini :

"Kami kira kuantitas perempuan yang dilibatkan dalam musyawarah rencana pembangunan Ohoi Elaar Lamagorang perlu ditingkatkan pada masa yang akan datang. Sebab dengan semakin tinggi kuantitas perempuan yang diikutsertakan dalam musyawarah rencana pembangunan Ohoi Elaar Lamagorang, maka tentunya akan mampu menjawab kebutuhan para perempuan terkait dengan realisasi pembangunan rill yang berpihak pada perempuan. Untuk kepentingan dimaksud, maka tentunya Pemerintah Ohoi Elaar Lamagorang perlu melakukan sosialisasi kepada perempuan menyangkut dengan pentingnya kuantitas perempuan yang dilibatkan dalam musyawarah rencana pembangunan Ohoi Elaar Lamagorang. Dengan cara ini diharapkan kuantitas perempuan yang dilibatkan dalam musyawarah rencana pembangunan Ohoi Elaar Lamagorang akan dapat ditingkatkan."

Dari wawancara tersebut dapat diketahui bahwa, kuantitas perempuan yang dilibatkan dalam musyawarah rencana pembangunan Ohoi Elaar Lamagorang perlu ditingkatkan pada masa yang akan datang. Sebab dengan semakin tinggi kuantitas perempuan yang diikutsertakan dalam musyawarah rencana pembangunan Ohoi Elaar Lamagorang, maka tentunya akan mampu menjawab kebutuhan para perempuan terkait dengan realisasi pembangunan rill yang berpihak pada perempuan. Untuk kepentingan dimaksud, maka tentunya Pemerintah Ohoi Elaar Lamagorang perlu melakukan sosialisasi kepada perempuan menyangkut dengan pentingnya kuantitas perempuan yang dilibatkan dalam musyawarah rencana pembangunan Ohoi Elaar Lamagorang. Dengan cara ini diharapkan kuantitas perempuan yang dilibatkan dalam musyawarah rencana pembangunan Ohoi Elaar Lamagorang akan dapat ditingkatkan.

Lebetubun, J. (2022). Partisipasi Perempuan dalam Perencanaan Pembangunan di Ohoi Elaar Lamagorang Kecamatan Kei Kecil Timur Selatan Maluku Tenggara. Journal of Government Science Studies, 1(1). 


\section{Kualitas Kontribusi Pemikiran Perempuan Dalam Musyawarah Rencana Pembangunan Ohoi}

Hal yang tidak bisa dikesampingkan begitu saja, yakni pelibatan perempuan dalam musyawarah rencana pembangunan ohoi (desa). Hal ini dikarenakan dengan semakin tinggi kualitas perempuan yang dilibatkan dalam musyawarah rencana pembangunan ohoi (desa), makan akan berkolerasi positif dengan aspek kualitas rill realisasi dari rencana pembangunan ohoi (desa) dalam bentuk pembangunan fisik dan non fisik.

Oleh karena itu, tentunya tidak hanya cukup dengan aspek kuantitas perempuan yang dilibatkan dalam musyawarah rencana pembangunan ohoi (desa) saja, tapi juga kualitas saja perempuan yang dilibatkan dalam musyawarah rencana pembangunan ohoi (desa). Hal ini menandakan bahwa baik itu kuantitas dan kualitas perempuan yang dilibatkan dalam musyawarah rencana pembangunan ohoi (desa) sama-sama vital.

Seiring dinamika sosial-politik yang terjadi di tanah air, perempuan yang dilibatkan dalam musyawarah rencana pembangunan ohoi (desa), termasuk juga pada kabupaten/kota di Provinsi Maluku menjadi perhatian serius. Tidak terkecuali kualitas perempuan yang dilibatkan dalam musyawarah rencana pembangunan di Ohoi Elaar Lamagorang Kecamatan Kei Kecil Timur Selatan Kabupaten Maluku Tenggara. Menyangkut dengan hal itu, berikut wawancara peneliti dengan Raja Ohoi Elaar Lamagorang pada 20 Oktober 2016 di Ohoi Elaar Lamagorang, bahwa :

"Kita tidak bisa berbicara menyangkut dengan kualitas kontribusi pemikiran perempuan yang dilibatkan dalam musyawarah rencana pembangunan di Ohoi Elaar Lamagorang. Hal ini dikarenakan dari sisi kuantitas kontribusi pemikiran perempuan yang dilibatkan dalam musyawarah rencana pembangunan di Ohoi Elaar Lamagorang sangat minim. Sehingga kita tidak bisa berbicara pada suatu kesimpulan yang nyata tentang kualitas kontribusi pemikiran perempuan yang dilibatkan dalam musyawarah rencana pembangunan di Ohoi Elaar Lamagorang. Untuk berbicara tentang kualitas kontribusi pemikiran perempuan yang dilibatkan dalam musyawarah rencana pembangunan di Ohoi Elaar Lamagorang, yang perlu dilakukan yakni menaikan kuantitas perempuan yang dilibatkan dalam musyawarah rencana pembangunan di Ohoi Elaar Lamagorang. Jika target menaikan kuantitas perempuan yang dilibatkan dalam musyawarah rencana pembangunan di Ohoi Elaar Lamagorang, maka tentunya kualitas kontribusi pemikiran perempuan yang dilibatkan dalam musyawarah rencana pembangunan di Ohoi Elaar Lamagorang bisa kita gambarkan seberapa persen memiliki output dalam menujang keberhasilan pemabngunan yang nyata di Ohoi Elaar Lamagorang."

Dari wawancara tersebut dapat diketahui bahwa, Pemerintah Ohoi Elaar Lamagorang tidak bisa berbicara menyangkut dengan kualitas kontribusi pemikiran perempuan yang dilibatkan dalam musyawarah rencana pembangunan di Ohoi Elaar Lamagorang. Hal ini dikarenakan dari sisi kuantitas kontribusi pemikiran perempuan yang dilibatkan dalam musyawarah rencana pembangunan di Ohoi Elaar Lamagorang sangat minim. Sehingga tidak bisa berbicara pada suatu kesimpulan yang nyata tentang kualitas kontribusi pemikiran perempuan yang dilibatkan dalam musyawarah rencana pembangunan di Ohoi Elaar Lamagorang. Untuk berbicara tentang kualitas kontribusi pemikiran perempuan yang dilibatkan dalam musyawarah rencana pembangunan di Ohoi Elaar Lamagorang, yang perlu dilakukan yakni menaikan kuantitas perempuan yang dilibatkan dalam musyawarah rencana pembangunan di Ohoi Elaar Lamagorang. Jika target menaikan kuantitas perempuan yang dilibatkan dalam musyawarah rencana pembangunan di Ohoi Elaar Lamagorang, maka tentunya kualitas kontribusi pemikiran perempuan yang dilibatkan dalam musyawarah rencana pembangunan di Ohoi Elaar Lamagorang bisa kita gambarkan seberapa persen memiliki output dalam menujang keberhasilan pemabngunan yang nyata di Ohoi 
Elaar Lamagorang.

Terlepas dari itu, kualitas perempuan yang dilibatkan dalam musyawarah rencana pembangunan di Ohoi Elaar Lamagorang bisa diukur. Hal ini terjadi jika kualitas perempuan yang dilibatkan dalam musyawarah rencana pembangunan di Ohoi Elaar Lamagorang juga terpenuhi. Untuk hal dimaksud maka yang perlu dilakukan adalah kualitas perempuan yang dilibatkan dalam musyawarah rencana pembangunan di Ohoi Elaar Lamagorang ditingkatkan pada waktu yang akan datang. Menyangkut dengan hal ini berikut wawancara peneliti dengan Bapak Mesak Labetubun dan Bapak Daniel Larubun dari unsur Tokoh Adat di Ohoi Elaar Lamagorang pada 24 Oktober 2016 di Ohoi Elaar Lamagorang, bahwa :

"Kualitas kontribusi pemikiran perempuan dalam musyawarah rencana pembangunan Ohoi Elaar Lamagorang sampai dengan saat ini tidak bisa diukur, karena kuantitas kontribusi pemikiran perempuan dalam musyawarah rencana pembangunan Ohoi Elaar Lamagorang kecil. Pada waktu yang akan datang kualitas kontribusi pemikiran perempuan dalam musyawarah rencana pembangunan Ohoi Elaar Lamagorang tidak bisa diukur sepanjang bisa dipenuhinya kuantitas kontribusi pemikiran perempuan dalam musyawarah rencana pembangunan Ohoi Elaar Lamagorang."

Dari wawancara tersebut dapat diketahui bahwa, kualitas kontribusi pemikiran perempuan dalam musyawarah rencana pembangunan Ohoi Elaar Lamagorang sampai dengan saat ini tidak bisa diukur, karena kuantitas kontribusi pemikiran perempuan dalam musyawarah rencana pembangunan Ohoi Elaar Lamagorang kecil. Pada waktu yang akan datang kualitas kontribusi pemikiran perempuan dalam musyawarah rencana pembangunan Ohoi Elaar Lamagorang tidak bisa diukur sepanjang bisa dipenuhinya kuantitas kontribusi pemikiran perempuan dalam musyawarah rencana pembangunan Ohoi Elaar Lamagorang.

\section{Aspek Budaya Yang Mendukung Keterlibatan Perempuan Dalam Musyawarah Rencana Pembangunan Ohoi}

Salah satu aspek yang membuat perempuan minim terlibat dalam musyawarah rencana pembangunan ohoi (desa) yakni budaya. Hal ini dikarenakan budaya kita di tanah air di dominasi oleh budaya patrilineal, dimana berbagai bidang kehidupan sosial-kemasyarakatan selalu merupakan urusan dan tanggungjawab pria. Aspek ini-lah yang kemudan berdampak negativ terhadap rendahnya partisipasi perempuan dalam musyawarah rencana pembangunan ohoi (desa).

Agar bisa meningkatkan partisipasi perempuan dalam musyawarah rencana pembangunan ohoi (desa), maka tentunya perlu diciptakan budaya yang egaliter, dimana perempuan juga memiliki hak untuk bisa terlibat dalam musyawarah rencana pembangunan ohoi (desa), yang setara dengan hak pria untuk bisa terlibat dalam musyawarah rencana pembangunan ohoi (desa). Sehingga tidak berdampak pada adanya dominasi pria terhadap perempuan.

Fenomena demikian juga terjadi di Ohoi Elaar Lamagorang Kecamatan Kei Kecil Timur Selatan Kabupaten Maluku Tenggara, dimana aspek budaya yang membuat perempuan minim terlibat dalam musyawarah rencana pembangunan. Atas dasar itu, maka perlu diciptakan budaya yang egaliter, dimana perempuan juga memiliki hak untuk bisa terlibat dalam musyawarah rencana pembangunan Ohoi Elaar Lamagorang, yang setara dengan hak pria untuk bisa terlibat dalam musyawarah rencana pembangunan Ohoi Elaar Lamagorang. Menyangkut dengan hal ini berikut wawancara peneliti dengan Raja Ohoi Elaar Lamagorang............................pada 20 Oktober 2016 di Ohoi Elaar Lamagorang, bahwa :

"Memang benar salah satu hal yang membuat perempuan minim terlibat dalam musyawarah rencana pembangunan di Ohoi Elaar Lamagorang yakni budaya. Hal ini dikarenakan budaya di Ohoi Elaar Lamagorang masih dominasi oleh budaya

Lebetubun, J. (2022). Partisipasi Perempuan dalam Perencanaan Pembangunan di Ohoi Elaar Lamagorang Kecamatan Kei Kecil Timur Selatan Maluku Tenggara. Journal of Government Science Studies, 1(1). 
yang menempatkan laki-laki sebagai figure yang harus mengurusi dan bertanggunjawab terhadap berbagai bidang kehidupan sosial-kemasyarakatan. Konsekuensi dari dominannya budaya yang menempatkan laki-laki sebagai figure yang harus mengurusi dan bertanggunjawab terhadap berbagai bidang kehidupan sosial-kemasyarakatan berdampak pada minimnya keterlibatan perempuan dalam musyawarah rencana pembangunan di Ohoi Elaar Lamagorang."

Dari wawancara tersebut dapat diketahui bahwa, salah satu hal yang membuat perempuan minim terlibat dalam musyawarah rencana pembangunan di Ohoi Elaar Lamagorang yakni budaya. Hal ini dikarenakan budaya di Ohoi Elaar Lamagorang masih dominasi oleh budaya yang menempatkan laki-laki sebagai figure yang harus mengurusi dan bertanggunjawab terhadap berbagai bidang kehidupan sosial-kemasyarakatan. Konsekuensi dari dominannya budaya yang menempatkan laki-laki sebagai figure yang harus mengurusi dan bertanggunjawab terhadap berbagai bidang kehidupan sosial-kemasyarakatan berdampak pada minimnya keterlibatan perempuan dalam musyawarah rencana pembangunan di Ohoi Elaar Lamagorang.

Terlepas dari itu, pada masa yang akan datang perlu diciptakan budaya yang egaliter, dimana perempuan juga memiliki hak untuk bisa terlibat dalam musyawarah rencana pembangunan ohoi (desa), yang setara dengan hak pria untuk bisa terlibat dalam musyawarah rencana pembangunan ohoi (desa). Sehingga tidak berdampak pada adanya dominasi pria terhadap perempuan. Menyangkut dengan hal ini berikut wawancara peneliti dengan Bapak Mesak Labetubun dan Bapak Daniel Larubun dari unsur Tokoh Adat di Ohoi Elaar Lamagorang pada 24 Oktober 2016 di Ohoi Elaar Lamagorang, bahwa :

"salah satu aspek vital yang membuat perempuan hanya sedikit mengambil bagian dalam musyawarah rencana pembangunan di Ohoi Elaar Lamagorang adalah aspek budaya. Sebab budaya di Ohoi Elaar Lamagorang masih dominasi oleh budaya yang menempatkan kaum pria sebagai sosok figure yang harus bertanggunjawab terhadap berbagai bidang kehidupan sosial-kemasyarakatan. Akibatnya berimplikasi yang tidak terlampau baik terhadap keterlibatan perempuan dalam musyawarah rencana pembangunan di Ohoi Elaar Lamagorang."

Dari wawancara tersebut dapat diketahui bahwa, salah satu aspek vita yang membuat perempuan hanya sedikit mengambil bagian dalam musyawarah rencana pembangunan di Ohoi Elaar Lamagorang adalah aspek budaya. Sebab budaya di Ohoi Elaar Lamagorang masih dominasi oleh budaya yang menempatkan kaum pria sebagai sosok figure yang harus bertanggunjawab terhadap berbagai bidang kehidupan sosial-kemasyarakatan. Akibatnya berimplikasi yang tidak terlampau baik terhadap keterlibatan perempuan dalam musyawarah rencana pembangunan di Ohoi Elaar Lamagorang.

\section{Kesimpulan}

Adapun kesimpulan dari penelitian ini dapat dikemukakan sebagai berikut :

a. Di Ohoi Elaar Lamagorang kesadaran perempuan untuk berpartisipasi dalam musyawarah rencana pembangunan ohoimasih minim. Sebab rata-rata para perempuan masih sibuk dengan aktifitasnya masing-masing, baik itu sebagai ibu rumah tanggah dan sebagai pekerja di instansi pemerintah dan swasta. Sehingga tidak bisa menyempatkan waktunya untuk mengikuti musyawarah rencana pembangunan ohoi.

b. Kuantitas perempuan yang dilibatkan dalam musyawarah rencana pembangunan Ohoi Elaar Lamagorang masih sedikit. Sebab mayoritas perempuan masih sibuk dengan aktifitasnya masing-masing, baik itu sebagai ibu rumah tanggah dan sebagai pekerja di instansi pemerintah dan swasta. Sehingga mereka tidak bisa menyempatkan waktunya untuk mengikuti musyawarah rencana pembangunan ohoi. 
c. Pemerintah Ohoi Elaar Lamagorang tidak bisa merespons pembicaraan menyangkut dengan kualitas kontribusi pemikiran perempuan yang dilibatkan dalam musyawarah rencana pembangunan di Ohoi Elaar Lamagorang. Sebab dari sisi kuantitas kontribusi pemikiran perempuan yang dilibatkan dalam musyawarah rencana pembangunan di Ohoi Elaar Lamagorang sangat minim.

d. Salah satu hal yang membuat perempuan minim terlibat dalam musyawarah rencana pembangunan di Ohoi Elaar Lamagorang yakni budaya. Hal ini dikarenakan budaya di Ohoi Elaar Lamagorang masih dominasi oleh budaya yang menempatkan laki-laki sebagai figur yang harus mengurusi dan bertanggunjawab terhadap berbagai bidang kehidupan sosialkemasyarakatan

\section{Referensi}

Arif, Budiman. (1981). Pembagian Kerja Secara Seksual. Jakarta:Gramedia.

Antoft, K dan Novack, J. (1998). Grassroots Democracy: Local Government in the Maritimes. Nova Scotia: Henson College and Dalhousie University.

Goetze, Denis. (2014). Peran Wanita Dalam Pembangunan Perdesaan, www.kompasiana.com

Heglo H. Hugh dalam Abidin Zainal Said. (2004). Kebijakan Publik, Yayasan Pancur Siwah, Jakarta

Harisun. (2011). Pelayanan Publik Pemerintah Daerah, Fakultas Ilmu Sosial dan Ilmu Politik Universitas Lampung, Bandar Lampung,

Hasibuan, Malayu, SP. (2007). Manajemen Sumber Daya Manusia (Edisi Revisi), Bumi Aksara, Jakarta

Sastropoetro Santoso. (1998). Partisipasi, Komunikasi, Persuasi dan Disiplin Dalam Pembangunan Nasional, Alumni, Bandung

Salisbury, Robert, H. (1998). The Analysis of Public Policy : A Search for Theo-ries and Roles dalam Austin Ranney (e.d). Political Science and Public Policy, Markham, Chicago

Suyanto, S.R. (2008). Budidaya ikan lele (edisi revisi). Penebar Swadaya. Jakarta,

Sugiyono. (2003). Metode Penelitian. Bandung: Alfabeta.

Tjiptono, Fandi. 2006. Prinsip-Prinsip Total Quality Service, Andi Publisher, Yogyakarta

Tuanaya, W., \& Wance, M. (2021). Wayame village government partnership pattern in handling COVID 19 in Ambon city. Turkish Journal of Physiotherapy and Rehabilitation, 32(3).

Ihalauw, J. J. (2008). Konstruksi Teori. Kompenen dan Proses, Jakarta, Grasindo.

Muluk, M.R. Khairul. (2008). Knowledge Management (Kunci Sukses Inovasi Pemerintah Daerah). Malang: Banyumedia

Wance, M., \& Djae, R. M. (2019). Modalitas Dinasti Ahmad Hidayat Mus Pada Pemilihan Kepala Daerah Di Maluku Utara 2018. Sosiohumaniora, 21(3), 256-268.

Wance, M., Muhtar, M., \& Kaliky, P. I. (2020). PKM Penyelenggaraan Pemerintahan Dalam Perencanaan Pembangunan Negeri Hila Kabupaten Maluku Tengah. CARADDE: Jurnal Pengabdian Kepada Masyarakat, 2(2), 229-338.

Zainun Buchori. (1993). Administrasi dan Manajemen Sumber Daya Manusia, Ghalia Indonesia, Jakarta

Lebetubun, J. (2022). Partisipasi Perempuan dalam Perencanaan Pembangunan di Ohoi Elaar Lamagorang Kecamatan Kei Kecil Timur Selatan Maluku Tenggara. Journal of Government Science Studies, 1(1). 